Original investigation

Open Access

\title{
Serum leptin and its relation to anthropometric measures of obesity in pre-diabetic Saudis
} Nasser M Al-Daghri*1, Omar S Al-Attas², Khalid Al-Rubeaan², Mehad Mohieldin ${ }^{4}$, Mohammad Al-Katari ${ }^{5}$, Alan F Jones ${ }^{6}$ and Sudhesh Kumar?

Address: ${ }^{1}$ Biochemistry Department, College of Science, King Saud University, Riyadh, Saudi Arabia, ${ }^{2}$ Biochemistry Department, College of Science, King Saud University, Riyadh, Saudi Arabia, ${ }^{3}$ Medicine Department, College of Medicine, King Saud University, Riyadh, Saudi Arabia, ${ }^{4}$ Diabetic Center, KAUH, Riyadh, Saudi Arabia, ${ }^{5}$ Diabetic Center, KAUH, Riyadh, Saudi Arabia, ${ }^{6}$ Clinical Biochemistry, Birmingham Heartlands Hospital, Birmingham, B9 5SS, UK and 7Warwick Medical School, Diabetes \& Metabolism Unit, University of Warwick, Coventry, CV4 7AL, UK

Email: Nasser M Al-Daghri* - aldaghri2000@hotmail.com; Omar S Al-Attas - omrattas@ksu.edu.sa; Khalid Al-Rubeaan - krubeaan@ksu.edu.sa; Mehad Mohieldin - mohieldin@ksu.edu.sa; Mohammad Al-Katari - malkatari@ksu.edu.sa; Alan F Jones - afjones@doctors.org.uk; Sudhesh Kumar - Sudhesh.Kumar@warwick.ac.uk

* Corresponding author

Published: 7 July 2007

Cardiovascular Diabetology 2007, 6:18 doi:10.1 186/1475-2840-6-18

This article is available from: http://www.cardiab.com/content/6/1/18

(c) 2007 Al-Daghri et al; licensee BioMed Central Ltd.

This is an Open Access article distributed under the terms of the Creative Commons Attribution License (http://creativecommons.org/licenses/by/2.0), which permits unrestricted use, distribution, and reproduction in any medium, provided the original work is properly cited.

\begin{abstract}
Background: Little information is available on leptin concentrations in individuals with IGT. This study aims to determine and correlate leptin levels to anthropometric measures of obesity in prediabetic, (IFG and IGT), type 2 diabetic and normoglycaemic Saudis.

Methods: 308 adult Saudis (healthy controls $n=80$; pre-diabetes $n=86$; Type 2 diabetes $n=142$ ) participated. Anthropometric parameters were measured and fasting blood samples taken. Serum insulin was analysed, using a solid phase enzyme amplified sensitivity immunoassay and also leptin concentrations, using radio-immunoassay. The remaining blood parameters were determined using standard laboratory procedures.
\end{abstract}

Results: Leptin levels of diabetic and pre-diabetic men were higher than in normoglycaemic men (I 2.4 [3.2-72] vs 3.9 [0.8-20.0] ng/mL, (median [interquartile range], $\mathrm{p}=0.000 \mathrm{I}$ ). In females, leptin levels were significantly higher in pre-diabetic subjects $(14.09[2.8-44.4] \mathrm{ng} / \mathrm{mL}$ ) than in normoglycaemic subjects $(10.2[0.25-34.8] \mathrm{ng} / \mathrm{mL})(\mathrm{p}=0.046)$. After adjustment for BMI and gender, hip circumference was associated with $\log$ leptin $(p=0.006$ with $R 2=0.086)$ among all subjects.

Conclusion: Leptin is associated with measures of adiposity, hip circumference in particular, in the non-diabetic state among Saudi subjects. The higher leptin level among diabetics and pre-diabetics is not related to differences in anthropometric measures of obesity.

\section{Background}

Saudi Arabia, a Middle Eastern country with a population of 22 million, has undergone significant economic and cultural changes over the past thirty years. Approximately $60 \%$ of the population are urbanised and have adopted a 'Westernised' lifestyle in terms of diet and physical activity 
[1]. Obesity and associated components of the metabolic syndrome have become increasingly common in the Saudi population, which may partially explain the increased incidence of coronary heart disease (CHD) [2$7]$. In the USA, $17.1 \%$ of overweight adults aged $45-74$ years were found to have impaired glucose tolerance (IGT); $11.9 \%$ had impaired fasting glucose (IFG); $22.6 \%$ had prediabetes; and 5.6\% had both IGT and IFG [8].

Increased risk of CHD in subjects with IGT is supported by data from the Honolulu [8], Chicago [9] and Islington [10] heart studies, which demonstrated that mortality from CHD increased gradually as glucose tolerance deteriorated, with no apparent threshold value. In 1997, the American Diabetes Association (ADA) defined pre-diabetes as fasting plasma glucose (FPG) $6.1-7.0 \mathrm{mmol} / \mathrm{L}$ $(110-126 \mathrm{mg} / \mathrm{dl})$ [11]. The choice of the $6.1 \mathrm{mmol} / \mathrm{L}$ threshold was based partly on the increased risk of developing both microvascular and macrovascular complications above this level [11]. However, it has now been shown that the fasting glycaemia threshold of $6.1 \mathrm{mmol} /$ $\mathrm{L}$ does not create a category of glucose homeostasis equivalent to that of IGT, either for the subsequent development of diabetes or CHD [12].

Diabetes increases the risk of developing cardiovascular disease by $2-3$ times and increases by as much as $50 \%$ the risks of non-cardiovascular mortality associated with this condition [13-15]. This high risk is not completely explained by the traditional risk factors $[16,17]$. Pre-diabetes is also associated with cardiovascular diseases (CVD) $[18,19]$, but it is unclear if it is an independent risk factor, because it commonly co-exists with other cardiovascular risk factors present in the metabolic syndrome. The overall prevalence of type 2 diabetes in Saudi adults is $23.7 \%$ [20] while the overall prevalence of CHD is $5.5 \%$ [5]. However, the percentage of Saudi subjects who had an FPG in the impaired fasting glucose range $(6.1-7.0 \mathrm{mmol} /$ L) was $14.1 \%[7]$.

In human beings, serum leptin concentration is directly proportional to body fat mass, but it is leptin resistance and not leptin deficiency per se which is regarded as a pathogenic mechanism in human obesity. Leptin concentrations vary widely among individuals with similar fat mass, indicating other possible factors for its determination $[21,22]$. Leptin may be a marker of risk of CHD, at least in males, and contributes to the CHD risk profile in subjects with insulin resistance [23]. Not much information is available on leptin concentrations in individuals with IGT and to our knowledge there has been no study of leptin in pre-diabetics within the region.

This study aims to determine and compare the serum leptin concentrations of diabetic and non-diabetic patients with those in patients who have pre-diabetes and to correlate it with anthropometric measures of obesity.

\section{Methods \\ Subjects}

In the present study, subjects were selected from the roster of adult, ambulant, non-pregnant patients attending the Diabetes Center at the King Abdulaziz University Hospital in Riyadh, Saudi Arabia. Ethical approval was obtained from the local institution's review committee and consent was obtained from all participants. For the purposes of this study, subjects were classified into categories of abnormal glucose homeostasis if they had a single abnormal FPG. 142 patients had type-2 diabetes (FPG $>7.1$ $\mathrm{mmol} / \mathrm{L}$ ) (97 males and 45 females). All patients with diabetes were treated with a low-carbohydrate diet, with or without oral antidiabetetic agents, mainly glibenclamide and metformin. 86 pre-diabetic subjects ( 49 males and 37 females) were defined on the basis of modified ADA criteria [24]. Pre-diabetes was diagnosed when the fasting plasma glucose was between $5.6 \mathrm{mmol} / \mathrm{L}-7.0 \mathrm{mmol} / \mathrm{L}$ $(100-126 \mathrm{mg} / \mathrm{dL}) .80$ Saudi individuals (45 males and 35 females), with no prior history of CHD or diabetes, were recruited as controls (no diabetes).

\section{Anthropometric parameters}

All subjects underwent a full physical examination and completed a general questionnaire. Height was measured to the nearest $0.5 \mathrm{~cm}$ and weight to the nearest $0.1 \mathrm{~kg}$. Waist circumference $(\mathrm{cm})$ was measured at the horizontal circumference midway between the lowest rib margin and the iliac crest and the hip circumference $(\mathrm{cm})$ was measured at the maximum circumference over the buttocks. Body mass index (BMI) was calculated as weight $(\mathrm{kg})$ divided by height $(\mathrm{m})$ squared. Groups were matched for BMI.

\section{Laboratory methods}

Blood samples were collected after a 12-hour fast for the determination of glucose, insulin, total cholesterol, HDL, triglycerides, apolipoprotein A1 (apo A1), apolipoprotein A2 (apo A2) and leptin. All samples were stored at $-70^{\circ} \mathrm{C}$ prior to analysis by using routine laboratory methods, except for insulin and leptin assay. Insulin was analyzed by a solid phase enzyme amplified sensitivity immunoassay (Medgenix INS-ELISA, Biosource, Belgium). Leptin concentrations were measured by radio-immunoassay (Linco Research, St. Charles, MO). Homeostasis model assessment-insulin resistance (HOMA-IR) and $\beta$-cell function index were derived using the HOMA equation [25].

\section{Statistical Analysis}

Data were analysed using the Statistical Package for the Social Sciences (SPSS) version 10 (SPSS, Evanston, IL, USA) for Windows. Biochemical parameters not normally 
distributed were analyzed after being logarithmically transformed. Students' unpaired t-test and one-way analysis of variance (ANOVA) were used to compare the results of the different groups. Simple and partial correlation coefficients between the variables were determined and multiple regression analysis was performed to determine the relationships between the variables of interest. Data were expressed as mean (SD) or median (range); statistical significance was set at $\mathrm{p}<0.05$.

\section{Results}

Table 1 presents the clinical and metabolic characteristics of the male subjects. It is evident that those in the diabetes group were significantly older $(\mathrm{p}<0.0001)$, with higher fasting glucose and leptin levels $(\mathrm{p}<0.0001,0.012$ respectively) than those in the pre-diabetes and control groups. At the same time, the pre-diabetes group had significantly elevated systolic blood pressure $(\mathrm{p}=0.046)$ and fasting glucose levels ( $\mathrm{p}<0.0001)$, compared to the controls.

Table 2 highlights the clinical and metabolic parameters in the females. In the diabetes and pre-diabetes group, FPG and LDL were significantly higher than in the control. Total cholesterol was also significantly higher in women with diabetes $(\mathrm{p}=0.03)$.

Serum leptin was significantly higher in the men with diabetes than in their non-diabetic counterparts (12.4 [3.272 ]; $\mathrm{p}=0.0001)$. In the female patients, serum leptin was higher in those with pre-diabetes $(14.09$ [2.8-44.4]) than in the controls.
Stepwise linear regression analysis revealed a positive correlation between log leptin and hip circumference and $\mathrm{BMI}(\mathrm{R}=0.31, \mathrm{p}=0.002 ; \mathrm{R}=0.26, \mathrm{p}=0.006$ respectively $)$. Even after adjustment for BMI, there was a positive association between log leptin and hip circumference with an $\mathrm{R}^{2}$ $=0.086$ and $p$ value of 0.006 (see Figure 1 ). The rest of the findings were non-contributory.

\section{Discussion}

Insulin resistance is the common factor in a range of risk factors for atherosclerosis, specifically hypertension, dyslipidemia and abnormal glucose metabolism. As has been shown in other populations [26-29], the pre-diabetic males had a significantly higher systolic blood pressure and fasting plasma glucose than the control subjects had. Many [30,31], but not all studies [32,33] of the general population have shown a positive association of indices of insulin resistance with arterial wall changes, CHD and CVD. The clustering of risk factors increases the risk of atherosclerosis [34-36].

Data were presented according to gender, since it is already an established fact that leptin levels are significantly higher in women than in men. There are several possible explanations for the difference. One is that females have more adipose tissue than males, but a growing literature indicates that estrogen, especially at higher levels, will stimulate the production of leptin, whereas androgens will suppress the levels of leptin [37]. In this cross-sectional study, we found positive correlations between leptin and hip circumference in pre-diabetic patients. This is consistent with a previous study, which also showed that this group is at high risk of developing

Table I: Clinical characteristics and metabolic parameters of male subjects with type-2 diabetes, pre-diabetes and no diabetes

\begin{tabular}{|c|c|c|c|}
\hline & No Diabetes & Pre-diabetes & Type-2 Diabetes \\
\hline $\mathrm{N}$ & 45 & 49 & 97 \\
\hline Age (years) & $45.7(12.6)$ & $50.1(11.6)$ & $54.5(10.7)^{f}$ \\
\hline Systolic blood pressure $(\mathrm{mm} \mathrm{Hg})$ & $123.1(16.9)$ & $132.8(25.1)^{\mathrm{a}}$ & $130.7(17.5)$ \\
\hline Diastolic blood pressure $(\mathrm{mm} \mathrm{Hg})$ & $79.9(9.1)$ & $85.1(11.4)$ & $82.9(10.5)$ \\
\hline $\mathrm{BMI}\left(\mathrm{Kg} / \mathrm{m}^{2}\right)$ & $29.2(7.3)$ & $28.5(4.3)$ & $27.3(4.1)$ \\
\hline Waist $(\mathrm{cm})$ & $93.7(18.2)$ & $98.6(10.1)$ & $96.4(\mid 15.1)$ \\
\hline Hips (cm) & $95.9(15.7)$ & $100.5(13.9)$ & $99.8(14.4)$ \\
\hline Fasting Glucose (mmol/L) & $4.8(0.6)$ & $6 . I(0.4)^{f}$ & $13.7(5.0)^{f}$ \\
\hline Cholesterol (mmol/L) & $5.2(1.6)$ & $5.6(1.4)$ & $6.5(1.9)^{f}$ \\
\hline $\mathrm{HDL}(\mathrm{mmol} / \mathrm{L})$ & $0.94(0.3)$ & I.2(0.4) & $0.9(0.4)$ \\
\hline Triglyceride (mmol/L) & $1.8(0.6-6.7)$ & $1.9(0.7-6.3)$ & $2.5(1.6-15)$ \\
\hline $\mathrm{LDL}(\mathrm{mmol} / \mathrm{L})$ & $3.3(1.1)$ & $3.9(1.6)$ & $4.2(1.8)^{\mathrm{b}}$ \\
\hline Insulin $\mu \mathrm{mol} / \mathrm{L}^{*}$ & $12.6(2-99)$ & $12.3(2-36)$ & $16.2(2-70)$ \\
\hline Leptin $\mathrm{ng} / \mathrm{mL} *$ & $3.9(0.8-20)$ & $7.6(1.2-72)^{d}$ & $12.4(3.2-72)^{c}$ \\
\hline APO AI mg/dL & $0.9(0.3)$ & $0.9(0.5)$ & $0.9(0.3)$ \\
\hline APO A2 mg/dL & $0.4(0.1)$ & $0.4(0.1)$ & $0.3(0.1)$ \\
\hline HOMA-IR * & $3.3(0.3-23.8)$ & $3.5(0.5-10.2)$ & $9.6(1.1-49.7)^{\mathrm{e}}$ \\
\hline
\end{tabular}

Data are presented as means (SD) or as medians (interquartile range) for insulin, leptin and HOMA-IR data. The P-values shown are comparisons of metabolic characteristics for case control versus either prediabetic patients or those with T2DM: a) $0.046 ; b) P=0.03 ; c) P=0.012$; $d$ ) $P=0.004$; e) $p=0.001 ;$ f) $p<0.0001$. 
Table 2: Clinical characteristics and metabolic parameters of female subjects with type-2 diabetes, pre-diabetes and healthy control subjects

\begin{tabular}{|c|c|c|c|}
\hline & No diabetes & Pre-diabetes & Type-2 diabetes \\
\hline $\mathrm{N}$ & 35 & 37 & 45 \\
\hline Age (years) & $43.6(11.3)$ & $43.3(11.7)$ & $49.0(12.6)^{d}$ \\
\hline Systolic blood pressure $(\mathrm{mm} \mathrm{Hg})$ & $122.8(23.1)$ & 127.3(24.2) & $123.6(18.6)$ \\
\hline Diastolic blood pressure (mm Hg) & $79.4(16.5)$ & $79.8(8.03)$ & $80.7(10.3)$ \\
\hline BMI $\left(\mathrm{kg} / \mathrm{m}^{2}\right)$ & $30.4(6.4)$ & $32.5(8.4)$ & $32.5(10.3)$ \\
\hline Waist $(\mathrm{cm})$ & $90.5(12.5)$ & $91.8(13.5)$ & $96.2(17.9)$ \\
\hline Hips $(\mathrm{cm})$ & $105.3(14.1)$ & $104.8(17.9)$ & $106.7(20.8)$ \\
\hline Fasting Glucose (mmol/L) & $4.8(0.9)$ & $6.1(0.4)^{b}$ & $14 . \mid(5.5)^{\mathbf{b}}$ \\
\hline Cholesterol (mmol/L) & $5.2(1.3)$ & $5.3(I . I)$ & $6.6(1.9)^{b}$ \\
\hline $\mathrm{HDL}(\mathrm{mmol} / \mathrm{L})$ & $\mathrm{I} . \mathrm{I}(0.4)$ & $0.9(0.4)$ & $I . I(0.3)$ \\
\hline Triglyceride (mmol/L) & $1.9(1.9)$ & $1.6(0.9)$ & $2.6(1.4)$ \\
\hline $\mathrm{LDL}(\mathrm{mmol} / \mathrm{L})$ & $3.5(1.4)$ & $3.6(1.1)^{d}$ & $4.4(1.5)^{c}$ \\
\hline Insulin $(\mu \mathrm{mol} / \mathrm{L})^{*}$ & $15.2(2-62)$ & $13.5(6-26)$ & $14.04(1-52)$ \\
\hline Leptin $\mathrm{ng} / \mathrm{mL} *$ & $10.2(0.25-34.8)$ & $14.09(2.8-44.4)^{\mathrm{a}}$ & $13.3(3.6-49.1)$ \\
\hline APO AI mg/dL & $0.8(0.4)$ & $0.9(0.4)$ & $1.2(2.5)$ \\
\hline APO AII mg/dL & $0.4(0.1)$ & $0.4(0.1)$ & $0.4(0.2)$ \\
\hline HOMA IR * & $3.1(0.3-12.5)$ & $3.6(1.5-7.3)$ & $7.8(0.6-28.4)^{b}$ \\
\hline
\end{tabular}

*Data are presented as means (SD) or as medians (interquartile range) for insulin, leptin and HOMA-IR data. The P-values shown are comparisons of metabolic characteristics for case control versus either prediabetics or patients with T2DM: a) $0.046 ; b) P=0.03 ; c) p=0.004 ; d$ ) $P<0.00$ I

CHD [38]. The positive association with hip circumference remained significant after adjusting for gender and BMI, which confirmed the results in previous studies for healthy men and women $[39,40]$. With impaired glucose tolerance, small changes in circulating insulin also alter insulin levels [41].

Serum leptin concentration may contribute to the risk of CVD by altering lipid metabolism and contributing to hypertension via the activation of the sympathetic nervous system and increasing renal sodium re-absorption $[42,43]$. However, in our study there was no correlation between leptin and blood pressure. In another study, leptin signaling directly promoted atherosclerosis and may therefore represent a therapeutic target for the prevention of atherosclerosis [44]. Lichnovska and her colleagues in their recent report mentioned the significant role of serum leptin in the progression of insulin resistance, but this was not confirmed in the present study [45]. The difference can be due to the fact that the earlier study considered elderly and hyperlipemic patients, while the present study focused on pre-diabetic, diabetic and non-diabetic adults. Our results, however, confirm the results of Adamia et al., which reveal no correlation between leptin and insulin resistance [46].

A family history of diabetes was found to have a negative association with leptin in pre-diabetic patients; this confirms a previous study which reported that healthy lean non-diabetic Asian Indians are more insulin resistant than other ethnic groups, despite similarities in their living environment [47]. Waist circumference has been postu- lated to have closer associations with the biomarkers of CHD than BMI has [48]. The association of leptin to waist circumference (a surrogate for upper body obesity) and hip circumference confirms findings in Mexican American populations $[49,50]$. After adjustment for BMI, serum leptin concentrations in pre-diabetic men were independent of waist circumference, but in women they were associated with hip circumference. Hip circumference is a proxy measure of peripheral fat in serum leptin concentrations, aside from the fact that women have a significantly larger volume of subcutaneous fat than do men. In the control subjects, leptin concentrations were directly and significantly related to subcutaneous fat, with a strong inverse relationship to waist-hip ratio. When the results were considered according to gender, it was found that $33.1 \%$ of the male Saudis with waist circumference $>102 \mathrm{~cm}$, had diabetes. In female subjects, $27 \%$ of those with a high waist circumference $\geq 88 \mathrm{~cm}$ had diabetes, compared to only $13.4 \%$ of those with a normal waist circumference [20]. Leptin is related to waist and hip circumference and is directly proportional to body fat. However, in those with diabetes, this relationship is lost, reflecting the effect of other factors, including hyperinsulinaemia and the activation of sub-clinical inflammation.

\section{Conclusion}

The significant correlation of leptin to selected anthropometric measurements of obesity is confirmed in non-diabetic Saudi Subjects. In those with diabetes, this relationship is lost, reflecting the effect of other factors, including hyperinsulinaemia and the activation of subclinical inflammation. 


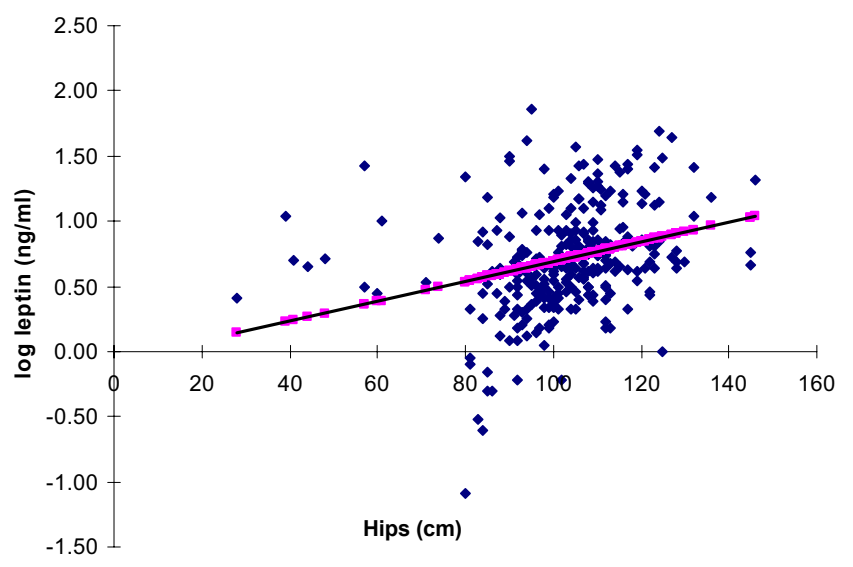

Figure I

Log leptin (ng/ml) vs. Hip circumference (cm). The correlation of log leptin $(\mathrm{ng} / \mathrm{mL})$ with hip circumference $(\mathrm{cm})$ using univariate analysis across all Saudi subjects, case controls, T2DM and pre-diabetic subjects. Blue denotes the actual values with the line of best fit shown in square $\left(R^{2}\right.$ $0.086 \mathrm{p}$-value $=0.006$ )

\section{Competing interests}

The author(s) declare that they have no competing interests.

\section{Authors' contributions}

NA for the concept and design as well as statistical analysis; OA for the drafting and revising of the manuscript; KA and $\mathrm{AJ}$ for the acquisition and interpretation of data; MM and $\mathrm{MK}$ for the screening and collection of data; KS for the concept and final revision of the manuscript. All the authors have read and approved the final version.

\section{Acknowledgements}

The authors extend their sincerest appreciation to Dr. Shaun Louie Sabico for his writing and editing assistance.

\section{References}

I. al-Nuaim AR, al-Rubeaan $\mathrm{K}$, al-Mazrou $\mathrm{Y}$, al-Attas $\mathrm{O}$, al-Daghari $\mathrm{N}$ Khoja T: High prevalence of overweight and obesity in Saudi Arabia. Int J Obes Relat Metab Disord 1996, 20(II):547-552.

2. al-Nuaim AR, al-Rubeaan $\mathrm{K}$, al-Mazrou $\mathrm{Y}$, al-Attas $\mathrm{O}$, al-Daghari $\mathrm{N}$ : Prevalence of hypercholesterolemia in Saudi Arabia, epidemiological study. Int J Cardiol 1996, 54(I):4I-49.

3. al-Shammari SA, Ali M, al-Shammari A, al-Maatouq M, Tennier A Armstrong K: Blood lipid concentrations and other cardiovascular risk factors among Saudis. Fam Pract 1994, I I (2): I 53- 158

4. Al-Dawood KM: Pattern of smoking among parents of schoolboys. Saudi Med J 2000, 2 I (8):735-739.

5. Al-Nozha MM, Arafah MR, Al-Mazrou YY, AL-Maatouq MA, Khan NB, Khalil MZ, Al-Khadra AH, Al-Marzouki K, Abdullah MA, Al-Harthi SS, Al-Shahid MS, Nouh MS, Al-Mobeireek A: Coronary Artery Disease in Saudi Arabia. Saudi Med J 2004, 25(9): I 165- I I7I.

6. Al-Turki YA: Overview of chronic diseases in the Kingdom of Saudi Arabia. Saudi Med J 2000, 2 I(5):499-500.

7. Al-Nuaim AR: Prevalence of glucose intolerance in urban and rural communities in Saudi Arabia. Diabet Med 1997, I 4(7):595-602.

8. Baron AD: Impaired glucose tolerance as a disease. Am / Cardiol 200I, 88(6A): $16 \mathrm{H}-19 \mathrm{H}$
9. Lowe LP, Liu K, Greenland P, Metzger BE, Dyer AR, Stamler J: Diabetes, asymptomatic hyperglycemia, and 22-year mortality in black and white men. The Chicago Heart Association Detection Project in Industry Study. Diabetes Care 1997 20(2): $163-169$.

10. Jackson CA, Yudkin JS, Forrest RD: A comparison of the relationships of the glucose tolerance test and the glycated haemoglobin assay with diabetic vascular disease in the community. The Islington Diabetes Survey. Diabetes Res Clin Pract 1992, I7(2): III-I 23.

II. [No authors listed]: Report of the Expert Committee on the Diagnosis and Classification of Diabetes Mellitus. Diabetes care 1997, 20(7): I I83-I I 97.

12. Meigs JB, Muller DC, Nathan DM, Blake DR, Andres R, Baltimore Longitudinal Study of Aging: The natural history of progression from normal glucose tolerance to type 2 diabetes in the $\mathrm{Bal}$ timore Longitudinal study of aging. Diabetes 2003, 52(6): $1475-\mid 484$.

13. Kannel WB, McGee DL: Diabetes and cardiovascular disease: The Framingham Study. JAMA 1979, 24I(1 9):2035-2038.

14. Gu K, Cowie CC, Harris MI: Mortality in adults with and without diabetes in a national cohort of the US population, I97I1993. Diabetes Care 1998, 2 I(7): 1138-1 I45.

15. Woodward M, Zhang X, Barzi F, Pan W, Ueshima H, Rodgers A, MacMahon S, Asia Pacific Cohort Studies Collaboration: The effects of diabetes on the risks of major cardiovascular diseases and death in the Asia-Pacific region. Diabetes Care 2003, 26(2):360-366.

16. Kannel WB: Lipids, diabetes, and coronary heart disease: insights from the Framingham Study. Am Heart J 1985, I I0(5): I I00-I I 07.

17. Stamler J, Vaccaro O, Neaton JD, Wentworth D: Diabetes, other risk factors, and I2-yr cardiovascular mortality for men screened in the Multiple Risk Factor Intervention Trial. Diabetes Care 1993, 16(2):434-444.

18. Barzilay JI, Spiekerman CF, Kuller LH, Burke GL, Bittner V, Gottdiener JS, Brancati FL, Orchard TJ, O'Leary DH, Savage PJ, Cardiovascular Health Study: Prevalence of clinical and isolated subclinical cardiovascular disease in older adults with glucose disorders: the Cardiovascular Health Study. Diabetes Care 200I, 24(7): 1233-1239.

19. Fisman EZ, Motro M, Tenenbaum A, Boyko V, Mandelzweig L, Behar $\mathrm{S}$ : Impaired fasting glucose concentrations in nondiabetic patients with ischemic heart disease: a marker for a worse prognosis. Am Heart J 200 I, I 4 I (3):485-490.

20. Al-Nozha MM, Al-Maatouq MA, Al-Mazrou YY, Al-Harthi SS, Arafah MR, Khalil MZ, Al-Khadra A, Al-Marzouki K, Nouh MS, Abdullah M, Attas O, Al-Shahid MS, Al-Mobeireek A: Diabetes mellitus in Saudi Arabia. Saudi Med J 2004, 25(II):1603-1610.

21. Lonnqvist F, Arner P, Nordfors L, Schalling M: Overexpression of the obese (ob) gene in adipose tissue of human obese subjects. Nat Med I995, I(9):950-953.

22. Considine RV, Sinha MK, Heiman ML, Kriauciunas A, Stephens TW Nyce MR, Ohannesian JP, Marco CC, McKee LJ, Bauer TL, et al: Serum immunoreactive-leptin concentrations in normalweight and obese humans. N Engl I Med 1996, 334(5):292-295.

23. Al-Daghri N, Al-Rubean K, Bartlett WA, Al-Attas O, Jones AF, Kumar $\mathrm{S}$ : Serum leptin is elevated in Saudi Arabian patients with metabolic syndrome and coronary artery disease. Diabet Med 2003, 20(10):832-837.

24. American Diabetes Association: Diagnosis and classification of diabetes mellitus. Diabetes Care 2004, 27(Suppl I):S5-SIO.

25. Matthews DR, Rudenski AS, Naylor BA, Treacher DF, Turner RC: Homeostasis model assessment: insulin resistance and betacell function from fasting plasma glucose and insulin concentrations in man. Diabetologia 1985, 28(7):4I 2-419.

26. Haffner SM, Stern MP, Hazuda HP, Mitchell BD, Patterson JK: Cardiovascular risk factors in confirmed prediabetic individuals. Does the clock for coronary heart disease start ticking before the onset of clinical diabetes? JAMA 1990, 263(21):2893-2898.

27. Medalie JH, Papier CM, Goldbourt U, Herman JB: Major factors in the development of diabetes mellitus in 10,000 men. Arch Intern Med 1975, I35(6):8I I-8I7.

28. McPhillips JB, Barrett-Connor E, Wingard DL: Cardiovascular disease risk factors prior to the diagnosis of impaired glucose 
tolerance and non-insulin-dependent diabetes mellitus in a community of older adults. Am J Epidemiol I 990, I 3 I (3):443-453.

29. Weyer C, Bogardus C, Mott DM, Pratley RE: The natural history of insulin secretory dysfunction and insulin resistance in the pathogenesis of type 2 diabetes mellitus. J Clin Invest 1999, I 04(6):787-794.

30. Pyorala M, Miettinen $\mathrm{H}$, Laakso $M$, Pyorala K: Hyperinsulinemia and the risk of stroke in healthy middle-aged men: the 22year follow-up results of the Helsinki Policemen Study. Stroke |998, 29(9): | 860- |866.

31. Jarrett RJ: Why is insulin not a risk factor for coronary heart disease? Diabetologia 1994, 37(9):945-947.

32. Niskanen L, Rauramaa R, Miettinen $H$, Haffner SM, Mercuri M, Uusitupa M: Carotid artery intima - media thickness in elderly patients with NIDDM and in nondiabetic subjects. Stroke 1996, 27( I I): 1986-1992.

33. Welin L, Eriksson H, Larsson B, Ohlson LO, Svardsudd K, Tibblin G: Hyperinsulinaemia is not a major coronary risk factor in elderly men: The study of men born in 1913. Diabetologia 1992 35(8):766-770.

34. DeFronzo RA, Ferrannini E: Insulin resistance. A multifaceted syndrome responsible for NIDDM, obesity, hypertension, dyslipidemia and atherosclerotic cardiovascular disease. Diabetes 1991, I4(3): I73-194.

35. Reaven GM, Laws A: Insulin resistance, compensatory hyperinsulinaemia, and coronary heart disease. Diabetologia 1994, 37(9):948-952.

36. Fujioka S, Matsuzawa $\mathrm{Y}$, Tokunaga K, Tarui S: Contribution of intra-abdominal fat accumulation to the impairment of glucose and lipid metabolism in human obesity. Metabolism 1987, 36(I):54-59.

37. Castracane VD, Henson MC: When did leptin become a reproductive hormone? Semin Reprod Med 2002, 20(2):89-92.

38. Alexander CM, Landsman PB, Teutsch SM: Diabetes mellitus, impaired fasting glucose, atherosclerotic risk factors, and prevalence of coronary heart disease. Am J Cardiol 2000, 86(9):897-902.

39. Zhong N, Wu XP, Xu ZR, Wang AH, Luo XH, Cao XZ, Xie H, Shan $P F$, Liao EY: Relationship of serum leptin with age, body weight, body mass index, and bone mineral density in healthy mainland Chinese women. Clin Chim Acta 2005, 35 I ( I2): $161-168$.

40. Maugeri D, Bonanno MR, Speciale S, Santangelo A, Lentini A, Russo MS, Calanna A, Malaguarnera M, Motta M, Testai' M, Panebianco P: The leptin, a new hormone of adipose tissue: clinical findings and perspectives in geriatrics. Arch Gerontol Geriatr 2002, 34(I):47-54

4I. Leonhardt W, Horn R, Brabant G, Breidert M, Temelkova-Kurktschiev T, Fucker K, Hanefeld M: Relation of free and specifically bound leptin to insulin secretion in patients with impaired glucose tolerance (IGT). Exp Clin Endocrinol Diabetes 1997, I07(I):46-52.

42. Asakawa H, Tokunaga K, Kawakami F: Relationship of leptin level with metabolic disorders and hypertension in Japanese type 2 diabetes mellitus patients. J Diabetes Complications 2001, I 5(2):57-62

43. Couillard C, Mauriege P, Prud'homme D, Nadeau A, Tremblay A, Bouchard C, Despres JP: Plasma leptin concentrations: gender differences and associations with metabolic risk factors for cardiovascular disease. Diabetologia 1997, 40( I 0): I I78-I I 84.

44. Reilly MP, Iqbal N, Schutta M, Wolfe ML, Scally M, Localio AR, Rader DJ, Kimmel SE: Plasma leptin levels are associated with coronary atherosclerosis in type 2 diabetes. J Clin Endocrinol Metab 2004, 89(8):3872-3878.

45. Lichnovska R, Gwozdziewiczova A, Hrebicek J: Gender differences in factors influencing insulin resistance in elderly hyperlipemic non-diabetic subjects. Cardiovasc Diabetol 2002, I:4.

46. Adamia N, Virsaladze D, Charkviani N, Skhirtladze M, Khutsishvili M: Effect of metformin therapy on plasma adiponectin and leptin levels in obese and insulin resistant postmenopausal females with type 2 diabetes. Georgian Med News 2007:52-55.

47. Liew CF, Seah ES, Yeo KP, Lee KO, Wise SD: Lean, nondiabetic Asian Indians have decreased insulin sensitivity and insulin clearance, and raised leptin compared to Caucasians and Chinese subjects. Int J Obes Relat Metab Disord 2003 27(7):784-789.
48. Lofgren I, Herron K, Zern T, West K, Patalay M, Shachter NS, Koo $\mathrm{SI}$, Fernandez ML: Waist circumference is a better predictor than body mass index of coronary heart disease risk in overweight premenopausal women. J Nutr 2004, I34(5): I 07|- 076

49. Haffner SM, Gingerich RL, Miettinen H, Stern MP: Leptin concentrations in relation to overall adiposity and regional body fat distribution in Mexican Americans. Int J Obes Relat Metab Disord 1996, 20(1 0):904-908.

50. Kafulafula G, Moodley J: Leptin levels in the obese African parturient. J Obstet Gynaecol 200I, 2 I (3):228-23I.
Publish with Biomed Central and every scientist can read your work free of charge

"BioMed Central will be the most significant development for disseminating the results of biomedical research in our lifetime. "

Sir Paul Nurse, Cancer Research UK

Your research papers will be:

- available free of charge to the entire biomedical community

- peer reviewed and published immediately upon acceptance

- cited in PubMed and archived on PubMed Central

- yours - you keep the copyright
Biomedcentral 